\title{
Bile acid and cholesterol excretion in human beings given soya-bean- and meat-protein-based diets: a study in ileostomy subjects
}

\author{
BY INGVAR BOSAEUS, BRITTMARIE SANDSTRÖM \\ AND HENRIK ANDERSSON \\ Dept of Clinical Nutrition, University of Gothenburg, Sahlgren's Hospital, \\ $S-41345$ Gothenburg, Sweden
}

(Received 14 April 1987 - Accepted 27 October 1987)

1. The effect of partial replacement of meat protein with three different soya-bean-protein products on bile acid and cholesterol excretion was studied in seven ileostomy subjects. Four different test diets containing $60 \mathrm{~g}$ meat, rice and bread protein, or a replacement of $250 \mathrm{~g}$ protein $/ \mathrm{kg}$ total dietary protein by soya-bean protein from soyabean flour, soya-bean concentrate or soya-bean isolate, were randomly assigned to the subjects in 2-d periods.

2. Ileostomy contents were collected at $2-h$ intervals during the day and in one portion during the night, and immediately deep-frozen to avoid bacteriological degradation. Bile acids and cholesterol were quantified by gas-liquid chromatography.

3. No difference in daily excretion of bile acids and cholesterol was noted between test diets. lleostomy sterol concentrations were lower when soya-bean products were fed.

4. Incorporation of moderate amounts of soya-bean products in solid diets does not seem to affect short-term sterol balance in man.

Soya-bean protein decreases serum cholesterol levels compared with animal protein in the rabbit (Hamilton \& Carroll, 1976; Huff et al. 1977, 1982). In hyperlipidaemic humans, replacement of dietary animal protein with soya-bean protein has been reported to lower serum cholesterol in several studies (Sirtori et al. 1979; Descovich et al. 1980; Wolfe et al. 1981; Goldberg et al. 1982), while others found no specific effect of soya-bean protein (Holmes et al. 1980; Shorey et al. 1981). In studies on normolipidaemic humans this effect has been small or absent (Carroll et al. 1978; van Raaij et al. 1981, 1982).

The mechanism of this hypocholesterolaemic effect is not clearly established (Gibney, 1982). In rabbits, the cholesterol-lowering effect of soya bean compared with casein was accompanied by an increased faecal steroid excretion (Huff \& Carroll, 1980; Pathirana et al. 1981) while in humans no consistent effect on serum cholesterol levels or faecal steroid excretion was found when soya-bean-protein replaced casein in formula diets (Grundy \& Abrams, 1983).

The type of soya-bean-protein product may be of importance, as a somewhat different metabolic response to soya-bean isolate compared with a cruder soya-bean concentrate has been reported (van Raaij et al. 1982). Also, in many studies a major part of the dietary protein has been replaced by soya bean, which does not seem realistic as dietary advice to most people. Soya-bean-protein products are, however, increasingly being used to extend or replace animal protein, and thus are included in small or moderate amounts in the diet of many people.

Because of the methodological problems associated with sterol-balance studies in humans, we have attempted to increase precision in measurements by the use of ileostomates as research subjects. With this study technique, bacterial degradation of bowel contents is minimized and bowel transit time is greatly diminished; both factors enhance

Address for correspondence: Dr I. Bosaeus, Dept of Clinical Nutrition, Sahlgren's Hospital, Annedalsklinikerna, S-413 45 Gothenburg, Sweden. 
Table 1. Sex, age, body height, body-weight and diagnosis for subjects

\begin{tabular}{cccccl}
\hline \hline $\begin{array}{c}\text { Subject } \\
\text { no. }\end{array}$ & Sex & $\begin{array}{c}\text { Age } \\
\text { (years) }\end{array}$ & $\begin{array}{c}\text { Body } \\
\text { ht }(\mathrm{m})\end{array}$ & $\begin{array}{c}\text { Body-wt } \\
(\mathrm{kg})\end{array}$ & Diagnosis \\
\hline 1 & $q$ & 57 & 1.69 & 76.3 & Rectal cancer \\
2 & 0 & 26 & 1.90 & 78.2 & Crohn's disease \\
3 & $q$ & 31 & 1.64 & 70.9 & Crohn's disease \\
4 & + & 24 & 1.63 & 50.8 & Crohn's disease \\
5 & 0 & 39 & 1.81 & 79.5 & Ulcerative colitis \\
6 & + & 40 & 1.67 & $59 \cdot 8$ & Crohn's disease \\
7 & $q$ & 42 & 1.64 & 57.4 & Crohn's disease \\
\hline
\end{tabular}

precision in measurements, reduce variation and make balance studies of short duration feasible (Sandberg et al. 1981; Tornquist et al. 1986).

We report here the short-term effects of replacing moderate amounts of meat protein with three different soya-bean-protein products on bile acid and cholesterol excretion in seven ileostomy subjects. Findings relating to apparent protein absorption and mineral balance have been published elsewhere (Sandström et al. 1986).

\section{SUBJECTS AND METHODS}

\section{Subjects}

Seven ileostomy subjects volunteered for the study. Sex, age, height, weight and diagnosis are given in Table 1 . Subjects nos. 2-6 had previously been proctocolectomized and had conventional terminal ileostomies. Subjects nos. 1 and 7 had a loop ileostomy (Fasth et al. 1980) sited close to the ileocaecal valve. All subjects were healthy and without symptoms or signs of recurrent bowel inflammation or liver/biliary dysfunction, as judged by history, clinical examination and routine laboratory tests. None of the subjects were on drug therapy at the time of the study. The ileostomies functioned properly, and the volumes of excreta were within normal range.

\section{Diets}

Experimental diets providing approximately $60 \mathrm{~g}$ protein were made from conventional food items. The main meals were based on meat protein, either as meat sauce or as meat pie. An example of a daily menu is given in Table 2 . The energy content of the diets was individually adjusted by adding protein-free bread and butter. The mean daily carbohydrate intake was $201 \mathrm{~g}$ on the soya-bean diets and $237 \mathrm{~g}$ on the meat diet. The mean fat intake was $107 \mathrm{~g} / \mathrm{d}$ for all diets. Soya-bean protein replaced $250 \mathrm{~g} / \mathrm{kg}$ total dietary protein by substitution of $500 \mathrm{~g} / \mathrm{kg}$ protein in bread and $300 \mathrm{~g} / \mathrm{kg}$ protein in meat sauce or pie for the main meals. The soya-bean-protein products used were: (1) soya-bean flour (Supro 50-4; Ralston Purina Co., St Louis, Mo. USA), containing (g/kg) 82 nitrogen, 7 starch, 147 nonstarch polysaccharides; (2) soya-bean concentrate (Unibit; Unimills, B.V., Zwijndrecht, The Netherlands), containing ( $\mathrm{g} / \mathrm{kg}$ ) $97 \mathrm{~N}, 9$ starch, 190 non-starch polysaccharides; (3) soya-bean isolate (Purina Protein 220, Ralston Purina Co.), containing (g/kg) $138 \mathrm{~N}, 1$ starch, 31 non-starch polysaccharides.

For $250 \mathrm{~g} / \mathrm{kg}$ protein replacement, 32, 25 and $19 \mathrm{~g}$ soya-bean flour, soya-bean concentrate and soya-bean isolate respectively, were used. Butter was used to replace meat fat in the soya-bean diets. Cholesterol intake (mg/d) was 291 (SE 10) on the meat-protein diet, 280 (SE 9) on the meat and soya-bean-flour diet, 276 (SE 10) on the meat and soya-bean- 
Table 2. Composition of test diets

\begin{tabular}{|c|c|c|c|c|}
\hline \multirow[b]{2}{*}{$\begin{array}{l}\text { Example of } \\
\text { daily menu }\end{array}$} & \multirow[b]{2}{*}{$\begin{array}{c}\text { Energy } \\
(\mathrm{MJ})\end{array}$} & \multirow{2}{*}{ 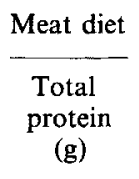 } & \multicolumn{2}{|c|}{ Meat and soya-bean diets } \\
\hline & & & $\begin{array}{l}\text { Total } \\
\text { protein } \\
\text { (g) }\end{array}$ & $\begin{array}{c}\text { Soya-bean } \\
\text { protein } \\
(\mathrm{g})\end{array}$ \\
\hline \multicolumn{5}{|l|}{ Breakfast } \\
\hline White bread & 1.38 & $7 \cdot 2$ & $7 \cdot 2$ & 3.6 \\
\hline Cheese & 0.42 & $7 \cdot 1$ & $7 \cdot 1$ & - \\
\hline Butter & 0.46 & - & - & - \\
\hline \multicolumn{5}{|l|}{ Snack } \\
\hline Protein-free roll & 0.63 & - & - & - \\
\hline Meat sauce & 1.34 & 16.9 & $17 \cdot 0$ & $5 \cdot 0$ \\
\hline Rice & 0.63 & $3 \cdot 0$ & $3 \cdot 0$ & - \\
\hline Protein-free bread & 0.17 & - & - & - \\
\hline \multicolumn{5}{|l|}{ Dinner } \\
\hline Meat pie & $2 \cdot 39$ & $20 \cdot 0$ & $20 \cdot 0$ & 5.9 \\
\hline Cucumber & 0.04 & - & - & - \\
\hline \multicolumn{5}{|l|}{ Evening } \\
\hline Sweet rolls & $1 \cdot 51$ & $6 \cdot 2$ & 6.0 & 3.0 \\
\hline Soft drink & 0.50 & $\ldots$ & - & - \\
\hline Total & $9 \cdot 47$ & $60 \cdot 4$ & $60 \cdot 4$ & 17.5 \\
\hline
\end{tabular}

concentrate diet, and 275 (SE 9) on the meat and soya-bean-isolate diet. Plant sterol intake (mg/d) was 64 (SE 3) on the meat-protein diet, 60 (SE 4) on the meat and soya-bean-flour diet, 54 (SE 4) on the meat and soya-bean-concentrate diet, and 62 (SE 6) on the meat and soya-bean-isolate diet. To keep the fibre content from sources other than soya-bean as low as possible, the only vegetable in these diets was peeled fresh cucumber. The subjects were offered a choice of low-alcohol beer, soft drinks, mineral water, and tea or coffee made from deionized water, and the drink was then kept constant throughout the study. No additional food consumption was allowed.

All the food was prepared in advance in the metabolic kitchen. The same batch of meat and flour was used for all subjects. Individual portions of the meals were kept in store at $-18^{\circ}$ and were thawed and heated on the day of consumption. The subjects were instructed not to leave any food, but if they did, they were to bring back the leftovers for analysis. A duplicate portion of the diet was collected for analysis each day during the study, homogenized and freeze-dried to constant weight as previously described (Sandberg et al. 1981).

\section{Experimental design}

The four test diets were given to each subject in 2-d periods. The order of diets was randomized. Subjects were on test diets during $4 \mathrm{~d}$ /week, from Monday morning to Friday morning, during which period two of the test diets were given. No dietary restrictions were imposed at the weekend. The study was preceded by a medical examination of the subjects, and thorough information was given about the study. Body-weight, height, and dietary and activity histories were taken for estimation of energy requirement. To assure compliance to the diet and to check the selected amount of food, a test day with one of the experimental diets also preceded the study. During the study, the subjects consumed one of the meals each day in the metabolic ward, under the supervision of a research dietician. The other 


\section{I. Bosaeus, Brittmarie Sandström and H. Andersson}

meals were provided each day for consumption at home. Ileostomy contents were collected for 24 -h periods. To avoid bacterial degradation, the ileostomy bags were changed every $2 \mathrm{~h}$ during the day, from 07.00 hours to retiring at night. The night bag was kept until 07.00 hours the next day. Each bag was immediately frozen on dry ice in a Dewar vessel (Karlsruher Glastechnik, Karlsruhe, West Germany), which the subject kept at home and delivered to the metabolic ward the next morning. The bags were weighed, stored at $-20^{\circ}$ and freeze-dried to constant weight. The freeze-dried ileostomy contents from each $24 \mathrm{~h}$ period were then pooled and homogenized for analysis.

\section{Analytical methods}

All analyses were made in duplicate. Fat in ileostomy contents was determined according to the method of van de Kamer et al. (1949). Starch and dietary fibre components of the diets and the soya-bean products were determined by the method of Theander \& Westerlund (1986). Cholesterol and plant sterols in food and ileostomy contents, and bile acids in ileostomy contents, were analysed as previously described (Bosaeus et al. 1986a,b). In short, internal standards ( 5 - $\alpha$-cholestane (Sigma Chemical Co., St Louis, Mo. USA) and hyodeoxycholic acid (Serva Feinbiochemika, Heidelberg, West Germany)) were added, freeze-dried ileostomy excreta were saponified and bile acids deconjugated by alkaline hydrolysis. After extraction and methylation with 2,2-dimethoxypropane, acid and neutral sterols were separated and quantified by gas-liquid chromatography using a Varian 3700 system (Varian Instruments, Palo Alto, Ca, USA). A $12.5 \mathrm{~m}$ SE-54 capillary column was used, with hydrogen as the carrier gas and flame ionization detection.

\section{Calculations and statistical methods}

Values are given as means with their standard errors. Bile acid and fat excretion are reported as means for each dietary period. The period mean of cholesterol excretion minus dietary cholesterol is reported as net cholesterol excretion. Mean bile acid plus net cholesterol excretion is termed net sterol excretion, which would be equivalent to the sterol balance concept used in long-term metabolic studies.

Comparisons of values from different dietary periods were made by two-way analysis of variance and differences assessed by Duncan's multiple-range test. Comparisons of values from day 1 and day 2 in each diet period was made by Wilcoxon's signed-ranks matchedpairs test. A computer package (MULREG 800, Idatron HB, Linköping, Sweden) was used for the actual calculations.

\section{Ethical considerations}

All subjects gave informed consent and the study protocol was approved by the Ethical Committee of Sahlgren's Hospital.

\section{RESULTS}

Ileostomy excretion results for the test diets are presented in Table 3 . Wet and dry weights increased on all $250 \mathrm{~g}$ soya-bean protein $/ \mathrm{kg}$ protein diets $(P<0.05)$. The increase in wet weight, compared with the meat-protein diet, averaged $19 \%$ on the meat and soya-beanisolate diet, $24 \%$ on the meat and soya-bean-flour diet, and $19 \%$ on the meat and soyabean-concentrate diet. Dry weight increased by 10,24 and $14 \%$ respectively. In contrast, there was no significant difference in fat, bile acid, net cholesterol or net sterol excretion between diets. Wet weight sterol concentration was higher $(P<0.05)$ on the meat-protein diet. The decrease on the soya-bean-protein diets averaged $14 \%$. The dry weight sterol concentration was lower $(P<0.05)$ on the soya-bean-flour and soya-bean-concentrate diets 
Table 3. Ileostomy excretion on the meat-protein and $250 \mathrm{~g} / \mathrm{kg}$ soya-bean-isolate, soyabean-flour and soya-bean-concentrate diets

(Values are given as means with their standard errors for seven subjects)

\begin{tabular}{|c|c|c|c|c|c|c|c|c|}
\hline & \multicolumn{2}{|c|}{ Meat protein } & \multicolumn{2}{|c|}{ Soya-bean isolate } & \multicolumn{2}{|c|}{ Soya-bean flour } & \multicolumn{2}{|c|}{ Soya-bean concentrate } \\
\hline & Mean & $\mathrm{SE}$ & Mean & SE & Mean & $\mathrm{SE}$ & Mean & SE \\
\hline Wet wt $(g / d)$ & 642 & 71 & $768^{*}$ & 106 & $798^{*}$ & 86 & $764^{*}$ & 84 \\
\hline Dry wt $(g / d)$ & 50 & $2 \cdot 7$ & $55^{*}$ & $5 \cdot 2$ & $62 \dagger$ & $4 \cdot 2$ & $57^{*}$ & $4 \cdot 2$ \\
\hline Fat (mmol/d) & 12 & $1 \cdot 7$ & 15 & $5 \cdot 5$ & 16 & $4 \cdot 3$ & 15 & $3 \cdot 2$ \\
\hline Bile acids (mg/d) & 1096 & 195 & 1134 & 242 & 1185 & 233 & 1138 & 204 \\
\hline Net cholesterol $(\mathrm{mg} / \mathrm{d})$ & 298 & 41 & 310 & 41 & 281 & 49 & 247 & 33 \\
\hline Net sterol $(\mathrm{mg} / \mathrm{d})$ & 1394 & 181 & 1444 & 223 & 1466 & 242 & 1385 & 192 \\
\hline \multicolumn{9}{|l|}{ Sterol concentration: } \\
\hline $\mathrm{mg} / \mathrm{g}$ wet wt & $2 \cdot 74$ & 0.30 & $2 \cdot 40^{*}$ & $0 \cdot 31$ & $2 \cdot 36^{\prime}$ & * 0.39 & $2 \cdot 27^{*}$ & $0 \cdot 27$ \\
\hline $\mathrm{mg} / \mathrm{g}$ dry wt & $33 \cdot 8$ & $3 \cdot 3$ & $31 \cdot 3$ & $3 \cdot 0$ & $28.8^{*}$ & $4 \cdot 3$ & $29 \cdot 7^{*}$ & $3 \cdot 1$ \\
\hline
\end{tabular}

* Significantly different from meat-protein diet $(P<0.05)$.

$\dagger$ Significantly different from all other diets $(P<0.05)$.

compared with the meat-protein diet. This decrease averaged $13 \%$. No significant difference in any variable, i.e. wet and dry weights, fat, bile acid or net cholesterol excretion was found between day 1 and day 2 of each diet period.

\section{DISCUSSION \\ Methodological considerations}

Ileostomy subjects offer a model for studies of small-intestinal absorption and excretion in which many of the difficulties of balance studies in subjects with an intact gut are overcome. Handling of ileostomy excreta is a routine matter for these subjects, in contrast to the constant supervision and encouragement needed to obtain complete faecal collections from normal healthy persons. Thus, confinement in a metabolic ward is not a practical necessity.

Frequent collection and immediate freezing of ileostomy bags minimizes bacterial alteration of ileostomy contents, as shown for dietary fibre (Sandberg et al. 1981), bile acids and cholesterol (Bosaeus et al. 1986 a,b). The absence of bacterial metabolites simplifies the quantitative determination of bile acids and neutral sterols.

The mean transit time for small intestinal passage of a single meal is reported to be 6-8 h, as measured by xylose excretion (Holgate \& Read, 1983), and $11 \mathrm{~h}$ as measured by a radionuclide technique (Englyst \& Cummings, 1985). The non-absorbed fraction of the intake for $1 \mathrm{~d}$ will be excreted before the next morning, and on a constant diet the dayto-day variation is low, making short-term balance studies possible (Tornqvist et al. 1986). It has been repeatedly shown that dietary residue is excreted within the same day in the ileostomist (Sandberg et al. 1981; Chapman et al. 1985; Englyst \& Cummings, 1985, 1986). Thus, we did not use markers for demarcation of diet periods, and ileostomy excreta were collected from the start of each diet. We could not find any differences in excretion when day 1 of each diet period (i.e. preceded by another diet, either experimental or self-selected) and day 2 (i.e. preceded by the same diet) were compared. Therefore, we regard this model appropriate for the study of short-term effects of dietary changes, while long-term effects have to be investigated with other techniques. 


\section{Effect of diets on sterol excretion}

In the present study, moderate amounts of meat protein were replaced by soya-bean products in solid diets made from ordinary food items. The $250 \mathrm{~g} / \mathrm{kg}$ replacement used is, in our judgement, realistic but probably represents an upper limit for daily intake in most people consuming ordinary Western-type diets. Under these conditions, we did not find any significant alteration of daily excretion of bile acids or cholesterol, when meat protein was partially replaced by soya-bean products. This is in accordance with the results of Grundy \& Abrams (1983), who found no consistent change in sterol balances when casein was replaced by soya-bean protein in liquid-formula diets. Potter \& Nestel (1976), however, reported higher sterol excretion on soya-bean milk than cow's milk in infants, but this was ascribed to the differences in dietary cholesterol and fatty acid composition. Fumagalli et al. (1982) found no difference in faecal steroid excretion in type II hypercholesterolaemic patients when textured soya-bean-protein replaced animal protein in low-fat diets, in spite of a clear hypocholesterolaemic effect. Thus, to our knowledge, there is as yet no evidence that soya-bean protein will affect short-term sterol balance in man, as it does in the rabbit (Huff \& Carroll, 1980; Pathirana et al. 1981).

Due to the increased wet and dry weights on the soya-bean-protein diets, sterol concentrations were lower when these diets were fed. The decrease was similar for all three soya-bean products as regards wet-weight concentrations, while the decrease in dry-weight sterol concentration was significant for the soya-bean-flour and soya-bean-concentrate diets only. These two cruder preparations contain larger amounts of dietary fibre than the soya-bean isolate, which might produce at least part of this effect. This would be in accordance with studies on soya-bean fibre (Tsai et al. 1983), although different soya-beanfibre preparations may have different effects (Schweizer et al. 1983). The decrease in sterol concentrations might be of some importance, as high faecal steroid concentrations have been implicated as a risk factor for cancer of the large intestine (Hill \& Aries, 1971; Reddy et al. 1975), although this relation is far from clear (International Agency for Research on Cancer Intestinal Microecology Group, 1977; Kay, 1981).

This work was supported by grants from the Swedish Medical Research Council (No. 19X570) and the National Swedish Board for Technical Development. The expert technical assistance of Ms Helena Göransson, Ms Kristina Hasselblad and Mr Nils-Gunnar Carlsson is gratefully acknowledged.

\section{REFERENCES}

Bosaeus, I., Carlsson, N. G. \& Andersson, H. (1986a). Scandinavian Journal of Gastroenterology 21, 891-896. Bosaeus, I., Carlsson, N. G., Sandberg, A. S. \& Andersson, H. (1986 b). Human Nutrition: Clinical Nutrition 40C, $429-440$.

Carroll, K. K., Giovannetti, P. M., Huff, M. W., Moase, O., Roberts, D. C. K. \& Wolfe, B. M. (1978). American Journal of Clinical Nutrition 31, 1312-1321.

Chapman, R. W., Sillery, J. K., Graham, M. M. \& Saunders, D. R. (1985). American Journal of Clinical Nutrition 41, 1244-1248.

Descovich, G. C., Ceredi, C., Gaddi, A., Benassi, M. S., Manning, G., Colombo, L., Cattin, L., Fontana, G., Senin, U., Mannarino, E., Caruzzo, C., Bertelli, E., Fragiacomo, C., Noseda, G., Sirtori, M. \& Sirtori, C. R. (1980). Lancet ii, 709-712.

Englyst, H. N. \& Cummings, J. H. (1985). American Journal of Clinical Nutrition 42, 778-787.

Englyst, H. N. \& Cummings, J. H. (1986). American Journal of Clinical Nutrition 44, 42-50.

Fasth, S., Hultén, L. \& Palselius, I. (1980). Acta Chirurgica Scandinavica 146, 203-207.

Fumagalli, R., Soleri, L., Farina, R., Musanti, R., Mantero, O., Noseda, G., Gatti, E. \& Sirtori, C. R. (1982). Atherosclerosis 43, 341-353.

Gibney, M. J. (1982). Proceedings of the Nutrition Society 41, 19-26. 
Goldberg, A. P., Lim, A., Kolar, J. B., Grundhauser, J. J., Steinke, F. H. \& Schonfeld, G. (1982). Atherosclerosis 43, 355-368.

Grundy, S. M. \& Abrams, J. J. (1983). American Journal of Clinical Nutrition 38, 245-252.

Hamilton, R. M. G. \& Carroll, K. K. (1976). Atherosclerosis 24, 47-62.

Hill, M. J. \& Aries, V. C. (1971). Journal of Pathology 104, 129-139.

Holgate, A. M. \& Read, N. W. (1983). Digestive Diseases and Sciences 28, 812-819.

Holmes, W. L., Rubel, G. B. \& Hood, S. S. (1980). Atherosclerosis 36, 379-387.

Huff, M. W. \& Carroll, K. K. (1980). Journal of Lipid Research 21, 546-558.

Huff, M. W., Hamilton, R. M. G. \& Carroll, K. K. (1977). Atherosclerosis 28, 187-195.

Huff, M. W., Roberts, D. C. K. \& Carroll, K. K. (1982). Atherosclerosis 41, 327-336.

International Agency for Research on Cancer Intestinal Microecology Group (1977). Lancet ii, $207-211$.

Kay, R. M. (1981). Cancer Research 41. 3774-3777.

Pathirana, C., Gibney, M. J. \& Taylor, T. G. (1981). British Journal of Nutrition 46, 421-430.

Potter, J. M. \& Nestel, P. J. (1976). American Journal of Clinical Nutrition 29, 546-551.

Reddy, B. S., Weisburger, J. H. \& Wynder, E. L. (1975). Journal of Nutrition 105, 878-884.

Sandberg, A. S., Andersson, H., Hallgren, B., Hasselblad, K. \& Isaksson, B. (1981). British Journal of Nutrition 45, 283-294.

Sandström, B., Andersson, H., Kivistö, B. \& Sandberg, A. S. (1986). Journal of Nutrition 116, 2209-2218.

Schweizer, T. F., Bekhechi, A. R., Koellreutter, B., Reimann, S., Pometta, D. \& Bron, B. A. (1983). American Journal of Clinical Nutrition 38, 1-11.

Shorey, R. L., Bazan, B., Lo, G. S. \& Steinke, F. H. (1981). American Journal of Clinical Nutrition 34, 1769-1778.

Sirtori, C. R., Gatti, E., Mantero, O., Conti, F., Agradi, E., Tremoli, E., Sirtori, M., Fraterrigo, L., Tavazzi, L. \& Kritchevsky, D. (1979). American Journal of Clinical Nutrition 32, 1645-1658.

Theander, O. \& Westerlund, E. (1986). Journal of Agricultural and Food Chemistry 34, 330-336.

Tornqvist, H., Rissanen, A. \& Andersson, H. (1986). British Journal of Nutrition 56, 11-16.

Tsai, A. C., Mott, E. L., Owen, G. M., Bennick, M. R., Lo, G. S. \& Steinke, F. H. (1983). American Journal of Clinical Nutrition 38, 504-511.

Van de Kamer, J. H., ten Bokkel Huinink, H. \& Weyers, H. A. (1949). Journal of Biological Chemistry 177, 347-355.

Van Raaij, J. M. A., Katan, M. B., Hautvast, J. G. A. J. \& Hermus, R. J. J. (1981). American Journal of Clinical Nutrition 34, 1261-1271.

Van Raaij, J. M. A., Katan, M. B., West, C. E. \& Hautvast, J. G. A. J. (1982). American Journal of Clinical Nutrition 35, 925934.

Wolfe, B. M., Giovannetti, P. M., Cheng, D. C. H., Roberts, D. C. K. \& Carroll, K. K. (1981). Nutrition Reports International 24, 1187-1198. 